\title{
The Impact of Behavioral Finance on Credit Card Users in Chennai City
}

\author{
N. Jannifer Rani, Anli Suresh
}

\begin{abstract}
The frequent change in the technology has given rise to many new innovative things in our country. And one among them is the debit and credit cards which people prefer using it for many things. This study aims at identifying the key factors determining the credit card usage like appearance of the card, credit limit, image of the issuer bank, marketing campaign, co-branding offerand also the reasons for using the credit cards like avoidance of risk, prestige power, immediate payment, cash withdrawal facility, safe online shopping by the customers in Chennai city. The factors like convenience, immediate payment, universal acceptance; fraud protection has the higher impact on the customers having credit cards.The study is restricted toChennai city with samples of 100 has been taken for the study by using simple random method.The concluding observation is that there is noted relationship between income of the users of credit cards and the variables determining the choice of credit cards.
\end{abstract}

Keywords : Convenience, Credit cards, Fraud protection, immediate payment, Universal acceptance.

\section{INTRODUCTION}

In the technological world, credit cards have suited to be a part and parcel of everyone's existence. The easy access of the credit cards has given people various chances for forming rational buying. Various customers are able to spend their credit cards widely, while some people cannot use it wisely because of their leisure spending and many other factors. In recent years, the use of credit cards has suited an area of profitable and societal concern. The credit card has become popular as a remittancemeans and has not assigned to the benefit of not taking cash and cheques .A credit card is a plastic card which is supplied by the monetary institution and permits the enjoyer to take money to purchase goods. A procured credit card is also a decent financial building choice for those with no credit past or bad financial standing. Beneath this secured disposition, the cardboard holder consent to down payment a definite quantity the card prior to they begin exploitation it, and that they cannot levyon the far side that quantity. As a result of this lower threat for the card-supplying bank as they will gather associate beforehand down payment just in case the bearer cannot reimburse, secured cards are the best to be accepted for. A balance delegate credit card is good for those that take a balance on one or a lot of credit cards. The card holder can transfer and consolidate existing master card balances on to a balance

Revised Manuscript Received on December 05, 2019.

* Correspondence Author

N. Jannifer Rani*, M.Phil Scholar, Madras University, Chennai, India.

Dr. Anli Suresh, Assistant Professor of Commerce, Madras Christian College, Chennai, India. delegate card, and should be able to reimburse that debt at one-third interest for an amount of ten months to virtually two years.

\section{REVIEW OF LITERATURE}

Hersh shefrin, Christina.M.Nicols (2014) in her study on "Credit card conduct, financial styles, and heuristics" has made four contributions in their study. It has identified the new data's and findings in the credit card utilization with respect to disburse and takeover. It also identifies the major backdrop of the newly appearing literature on monetary learning. There is a great variance in the monetary learning among the American consumers. And finally the credit card holders report that they have low confidence with regard to online technology to manage their finances.

Leo Vashkor Dewri (2016) in his study, "behavioral analysis of credit card utilizers in an emerging country:" Profit building has an important part to manage shopper disbursal attitude in numerous countries. People's republic of Bangladesh Pakistan and Asian countries are considered as lower middle financial gain countries that indicates that they don't have the important ability to extent their disbursal habits. During this regard the monetary organizations and the banks issuing credit cards are undergoing new disbursal behaviors of credit card bearers. The study aims to analyze the utilization pattern of credit card bearers in spite of rising government issues. The study has also identified the earnings and exploitation full credit limit, tendency to use the credit cards, compensation attitude, profession and utilization conduct of credit cards, e-payment attitude to remit the bill by various age teams.

Kubra Onder (2018) in his study, "The effect of credit card usage on consumer behavior" The credit cards being the popular tool is a vital role for sellers and manufacturers so as to live within the merchandise and to keep up their strength in today's fierce situation. It is actually a biggest tool for the buyers, not from the status or on delayed remittance advantage. However, the truth that the buying call in buyer concern begins with the disclosure of essential, the credit cards given by financial institutions to their user's sort of a gift result shopper's behaviors efficiently replace money enabling the buyers to shop for any product simply.

Gustav A Barbosa (2017) in his study, "financial anxiety and consumers' behavior on and in credit card repayment" This study reveals the instigation of economic concern and therefore the part that concern towards the economy plays in customers' credit card indemnify conduct . 
Investigative approximation with concern degree as factors quantity, first and refund recurrence on credit card and furthermore offer steady support to the hypothesis that problem relating to customers opinion of self, relating to utilization and borrowing behavior, like poor mental accounting on disbursement, combined disinterest and current prejudice behavior end in higher levels of concern. To the current finish higher monetary acquisition does not cause less concern however it will upgrade reimbursement rates on credit cards.

Wesley Mendes-Da-Silva (2012) in his study "Credit Card Risk Behavior on College Campuses: Evidence from Brazil" college students often times show they need very little ability once it involves employing a credit card a very accountable manner. This study deals with this matter in a very rising trade and in a developing manner. Brazil main center answered to a form concerning their credit card utilization habits.

\section{OBJECTIVES OF THE STUDY}

- To study the impact of behavioral finance towards credit card users in Chennai city.

- To analyze the rationale for using credit cards among the customers in Chennai city.

\section{RESEARCH METHODOLOGY}

The methodology acquired is descriptive based on the figures from the primary data questionnaire from the sample size which consist of 100 respondents in and around Chennai city through simple random sampling. This sample method is considered as the economical method for collecting data from large geographical area. This method is more economic and also faster but there is a chance for sampling error. The questionnaire consists of five-point Likert scales. Secondary data was collected from various sources like journals, reviews, and websites. After the data had been collected, it was processed \& tabulated directly in to SPSS 20 Software. SPSS version 20 statistical software was used and the results obtained thereby have been analyzed using factor analysis and correlation analysis and interpreted.

\section{A. Hypotheses for The Study}

- H1- There is no noted difference between income and Appearance of the card.

- H2- There is no noted difference between income and Co-branding offer.

- H3- There is no noted difference between income and Power by VISA, AMEX and Master card.

- H4-There is no noted difference between income and Credit Limit.

- H5-There is no noted difference between income and Marketing Campaign.

- H6-There is no noted difference between income and Image of issuer bank.

\section{RESULTS AND DISCUSSION}

Data Analysis and Interpretation - Demographic Profile

Table -1: Frequency Distribution: Age, Gender, Qualification, Occupation, Income

\begin{tabular}{|c|c|c|}
\hline Age & Freq. & $\%$ \\
\hline 20-25 years & & \\
\hline $25-30$ years & 40 & 40.0 \\
\hline Above 30 years & 32 & 32.0 \\
\hline Gender & 28 & 28.0 \\
\hline Male & & \\
\hline Female & 42 & 42.0 \\
\hline Qualification & 58 & 58.0 \\
\hline UG & & \\
\hline PG & 50 & 50.0 \\
\hline Professional course & 38 & 38.0 \\
\hline Occupation & 12 & 12.0 \\
\hline Private sector & & \\
\hline Public sector & 47 & 47.0 \\
\hline Semi public & 22 & 22.0 \\
\hline Own business & 19 & 19.0 \\
\hline Income & 12 & 12.0 \\
\hline Below Rs.20000 & & \\
\hline Rs.20000-Rs.30000 & 30 & 30.0 \\
\hline RS.30000-Rs.40000 & 24 & 24.0 \\
\hline Above Rs.40000 & 22 & 22.0 \\
\hline Sorce: Prinay Data Analsis & 24.0 \\
\hline
\end{tabular}

Source: Primary Data Analysis

Interpretation: Table 1 reveals that out of total 100 respondents in which $40 \%$ comes under the age group of 20-25 years where as 32\% fall under the age group of 25-30 years. There were $42 \%$ male respondents taken for the study and $58 \%$ of the study was done with female respondents. Out of 100 respondents, $50 \%$ belong to under graduation, $38 \%$ were under post-graduation, and $12 \%$ belong to professional course. There were $47 \%$ respondents who are working in private sectors $22 \%$ respondents were from public sector, $19 \%$ of the respondents are from semipublic industries, $12 \%$ of the respondents have their own business. Out of 100 respondents, $30 \%$ of the respondents have monthly income of below Rs.20000, 24\% of the respondents have Rs.20000-Rs.30000, 22\% of the respondents have Rs.30000-Rs. 40000 and $24 \%$ of the respondents have monthly earnings of above Rs. 40000 .

\section{Data Analysis and Interpretation1- Factor Analysis}

Table-2: KMO TEST

\begin{tabular}{|c|c|c|}
\hline \multicolumn{2}{|c|}{ KMO measure of sampling adequacy } & 0.853 \\
\hline \multirow{2}{*}{$\begin{array}{c}\text { Bartlett's test of } \\
\text { sphericity }\end{array}$} & Approximation .X2 & 305.334 \\
\cline { 2 - 3 } & Dof & 28 \\
\cline { 2 - 3 } & Sig. & .000 \\
\hline \multicolumn{2}{|c|}{ Significant level at 0.01 levels. Source: Primary data Analysis } \\
\hline
\end{tabular}

Significant level at 0.01 levels. Source: Primary data Analysis 
A KMO score of $85.3 \%$ is an allowable one and hence, the factors with fewer score can be dropped and the acceptable factors were selected for the study.

Table - 3: Communalities table

\begin{tabular}{|c|c|c|c|}
\hline \multirow{3}{*}{ Satisfaction } & Convenience & Initial & Extraction \\
\cline { 2 - 4 } & Avoidance of risk & 1.000 & .814 \\
\cline { 2 - 4 } & Prestige power & 1.000 & .795 \\
\hline \multirow{2}{*}{$\begin{array}{c}\text { Modes of } \\
\text { Safety }\end{array}$} & Immediate payment & 1.000 & .549 \\
\cline { 2 - 4 } & Safe online shopping & 1.000 & .784 \\
\hline
\end{tabular}

Table - 4: Total Variance Explained

\begin{tabular}{|c|c|c|c|c|c|c|}
\hline \multirow[b]{2}{*}{ Elements } & \multicolumn{3}{|c|}{ Initial Eigen values } & \multicolumn{3}{|c|}{ Extraction Sums of Squared Loadings } \\
\hline & Total & $\%$ of Variance & Cumulative $\%$ & Total & $\%$ of Variance & Cumulative $\%$ \\
\hline 1 & 4.059 & 33.822 & 33.822 & 4.059 & 33.822 & 33.822 \\
\hline 2 & 1.953 & 16.274 & 50.096 & 1.953 & 16.274 & 50.096 \\
\hline 3 & 1.794 & 14.946 & 65.042 & 1.794 & 14.946 & 65.042 \\
\hline 4 & 1.306 & 10.885 & 75.928 & 1.306 & 10.885 & 75.928 \\
\hline
\end{tabular}

Extraction Method: PCA-Principal Component Analysis.

Source: Primary Data Analysis

\section{Interpretation}

- Element1 is labeled as SATISFACTION which comprises of factors like convenience, avoidance of risk, prestige power where convenience has the higher score of $81.4 \%$ because people prefer only for their higher level of convenience.

- Element 2 labeled as MODES OF SAFETY which comprises of factors like immediate payment, safe online shopping, less cash on hand where immediate payment has the higher score of $78.4 \%$ because people tend to use the credit card of its fast payment mode.

\begin{tabular}{|c|c|c|c|}
\hline & Less cash on hand & 1.000 & .732 \\
\hline \multirow{3}{*}{$\begin{array}{c}\text { World Wide } \\
\text { Access }\end{array}$} & Works in any currency & 1.000 & .711 \\
\hline & Universal acceptance & 1.000 & .856 \\
\hline & Build your credit score & 1.000 & .748 \\
\hline \multirow{3}{*}{$\begin{array}{l}\text { Monetary } \\
\text { Forms }\end{array}$} & Reward programs & 1.000 & .700 \\
\hline & Cash back & 1.000 & .772 \\
\hline & Fraud protection & 1.000 & .908 \\
\hline \multicolumn{4}{|c|}{ Extraction method: Principal Component Analysis } \\
\hline \multicolumn{4}{|c|}{ Source: Primary Data Analysis } \\
\hline
\end{tabular}

\section{Data Analysis And Interpretation 2- Correlation Analysis}

- Element 3 labeled as WORLD WIDE ACCESS which comprises of factors like works in any currency, universal acceptance, build your credit score where universal acceptance has the higher credit score of $85.6 \%$ because of its acceptability worldwide.

- Element 4 labeled as MONETARY FORMS which comprises of factors like Reward Programs, cash back, Fraud protection where fraud protection has the highest score of $90.8 \%$ because of its high level of safety.

Hypothesis Testing: The existence of relationship between income and factors determining the choice of credit cards.

Table-5: Correlation analysis

\begin{tabular}{|c|c|c|c|c|c|c|c|c|}
\hline & & Income & $\begin{array}{l}\text { Appearance } \\
\text { of the card }\end{array}$ & $\begin{array}{l}\text { Co-branding } \\
\text { offer }\end{array}$ & $\begin{array}{l}\text { Powered by } \\
\text { AMEX, } \\
\text { Visa, } \\
\text { Master card }\end{array}$ & Credit limit & $\begin{array}{l}\text { Marketing } \\
\text { campaign }\end{array}$ & $\begin{array}{c}\text { Image of } \\
\text { the issuer } \\
\text { bank }\end{array}$ \\
\hline \multirow{3}{*}{ Income } & $\mathrm{r}$ & 1 & $.237(*)$ & $.295(* *)$ & $.197(*)$ & $.540(* *)$ & $.450(* *)$ & $.429(* *)$ \\
\hline & sig. (2-tailed) & & 0.17 & .003 & .049 & .000 & .000 & .000 \\
\hline & $\mathrm{N}$ & 100 & 100 & 100 & 100 & 100 & 100 & 100 \\
\hline \multirow{3}{*}{$\begin{array}{l}\text { Appearance of the } \\
\text { card }\end{array}$} & $\mathrm{r}$ & $.237(*)$ & 1 & .157 & $.352(* *)$ & $.219(*)$ & .156 & $.222(*)$ \\
\hline & sig. (2-tailed) & .017 & & .118 & .000 & .028 & .121 & .026 \\
\hline & $\mathrm{N}$ & 100 & 100 & 100 & 100 & 100 & 100 & 100 \\
\hline \multirow{3}{*}{ Co-branding offer } & $\mathrm{r}$ & $.295(* *)$ & .157 & 1 & $.423(* *)$ & .118 & $.214(*)$ & $.468(* *)$ \\
\hline & sig. (2-tailed) & .003 & .118 & & .000 & .242 & .033 & .000 \\
\hline & $\mathrm{N}$ & 100 & 100 & 100 & 100 & 100 & 100 & 100 \\
\hline \multirow{3}{*}{$\begin{array}{l}\text { Powered by } \\
\text { AMEX visa } \\
\text { master card }\end{array}$} & $\mathrm{r}$ & $.197(*)$ & $.352(* *)$ & $.423(* *)$ & 1 & $.240(*)$ & $.211(*)$ & $.487(* *)$ \\
\hline & sig. (2-tailed) & .049 & .000 & .000 & & .016 & .035 & \\
\hline & $\mathrm{N}$ & 100 & 100 & 100 & 100 & 100 & 100 & 100 \\
\hline Credit limit & $\mathrm{r}$ & $.540(* *)$ & $.219(*)$ & .118 & $.240(*)$ & 1 & $.368(* *)$ & $.604(* *)$ \\
\hline
\end{tabular}




\begin{tabular}{|c|c|c|c|c|c|c|c|c|}
\hline & & Income & $\begin{array}{l}\text { Appearance } \\
\text { of the card }\end{array}$ & $\begin{array}{l}\text { Co-branding } \\
\text { offer }\end{array}$ & $\begin{array}{l}\text { Powered by } \\
\text { AMEX, } \\
\text { Visa, } \\
\text { Master card }\end{array}$ & Credit limit & $\begin{array}{l}\text { Marketing } \\
\text { campaign }\end{array}$ & $\begin{array}{c}\text { Image of } \\
\text { the issuer } \\
\text { bank }\end{array}$ \\
\hline & sig. (2-tailed) & .000 & .028 & .242 & .016 & & .000 & .000 \\
\hline & $\mathrm{N}$ & 100 & 100 & 100 & 100 & 100 & 100 & 100 \\
\hline \multirow{3}{*}{$\begin{array}{l}\text { Marketing } \\
\text { campaign }\end{array}$} & $\mathrm{r}$ & $.450(* *)$ & .156 & $.214(*)$ & $.211(*)$ & $.368(* *)$ & 1 & $.417(* *)$ \\
\hline & sig. (2-tailed) & .000 & .121 & .033 & .035 & .000 & & .000 \\
\hline & $\mathrm{N}$ & 100 & 100 & 100 & 100 & 100 & 100 & 100 \\
\hline \multirow{3}{*}{$\begin{array}{l}\text { Image of the issuer } \\
\text { bank }\end{array}$} & $\mathrm{r}$ & $.429(* *)$ & $.222(*)$ & $.468(* *)$ & $.487(* *)$ & $.604(* *)$ & .417 & 1 \\
\hline & sig. (2-tailed) & .000 & .026 & .000 & .000 & .000 & .000 & \\
\hline & $\mathrm{N}$ & 100 & 100 & 100 & 100 & 100 & 100 & 100 \\
\hline \multicolumn{9}{|c|}{$\begin{array}{l}\text { ** Correlation is significant at the } 0.01 \text { level (2-tailed). } \\
* \text { Correlation is significant at the } 0.05 \text { level (2-tailed). } \\
\text { Source: Primary Data Analysis }\end{array}$} \\
\hline
\end{tabular}

Interpretation:

\section{H1- There is no noted difference between Income and Appearance of the card.}

The correlation table reveals that the Pearson's coefficient of correlation value for the relationship between income and appearance of card is 0.170 . This specifies that there is a weak positive relationship between these variables. Thus the null hypothesis H1 (There is no noted difference between Income and Appearance of the card) is rejected.

\section{H2- There is no noted difference between Income and co-branding offer.}

The correlation table reveals that the Pearson's coefficient of correlation value for the relationship between Income and co-branding offer is 0.003 . This specifies that there is a positive relationship between these variables. Thus the null hypothesis $\mathrm{H} 2$ (There is no noted difference between Income and co-branding offer) is rejected.

\section{H3- There is no noted difference between Income and power by VISA, AMEX and Master card.}

The correlation table reveals that the Pearson's coefficient of correlation value for the relationship between income and power by VISA, AMEX and Master card is 0.049 This specifies that there is a positive relationship between these variables. Thus the null hypothesis H3 (There is no noted difference between Income and power by VISA, AMEX and Master card) is rejected.

\section{H4- There is no noted difference between Income and Credit Limit.}

The correlation table reveals that the Pearson's coefficient of correlation value for the relationship between income and Credit Limit is 0.000 . This specifies that there is a weak positive relationship between these variables. Thus the null hypothesis H4 (There is no noted difference between Income andCredit Limit) is rejected.

\section{H5- There is no noted difference between Income and Marketing Campaign.}

The correlation table reveals that the Pearson's coefficient of correlation value for the relationship between income and
Marketing Campaign is 0.000 . This specifies that there is a positive relationship between these variables. Thus the null hypothesis H5 (There is no noted difference between Income and Marketing Campaign) is rejected.

\section{H6- There is no noted difference between Income and Image of issuer bank.}

The correlation table reveals that the Pearson's coefficient of correlation value for the relationship between income and Image of issuer bankis 0.000 . This specifies that there is a positive relationship between these variables. Thus the null hypothesis H6 (There is no noted difference between Income andImage of issuer bank) is rejected.

\section{FINDINGS FROM THE STUDY}

Factor analysis is comprised of four component satisfaction, modes of safety, worldwide access, and monetary forms. Each component has the highest score factor convenience, immediate payment, universal acceptance, and fraud protection respectively.

Correlation values also indicate that Income is almost independent of factors determining the choice of credit cards by the customers. The range of correlation with the choice credit card is between 0.604 and 0.118 and all factors have positive connection and statistically reliable at $(\mathrm{p}<0.001)$ except the variable Appearance of the card which is statistically significant at $(p<0.005)$.From the correlation analysis it can be observed that the null hypothesis is rejected and there exists positive connection between dependent variable Income and all the independent variables. Hence, there is a strong association between these factors in choice of credit cards.

\section{CONCLUSION\& SUGGESTIONS}

The study has resulted in higher the income of the customers, higher the use of credit cards. People tend to use the credit cards if they are wise in their spending. The credit cards demonstrate a significant part in everyone's life in purchasing and various other things. 
People must be aware of the credit limit, interest rate, and also people must have the tendency to use the credit cards, compensation rate, and e-payment attitudes of the customers. This empirical study has found out the relationship between the income and the factors determining the choice of credit cards.

\section{SCOPE FOR FURTHER RESEARCH}

This study has identified the major influencing factors of choice of credit cards. The study has focused only various variables for the option of credit cards and the reasons for using the credit cards. The future researchers can identify the satisfaction level and also the impact of the credit card in economic terms towards the growth of the economy. The future researchers can identify the impact on the part of the banks and the financial institutions issuing the credit cards.

\section{REFERENCES}

1. Gustav A Barbosa (2017) In his study, "financial anxiety and consumers behavior on and in credit card repayment" issued in journal of financial management, markets and institution vol.5, no.1, pp 35-66: ISSN 2282-717X.

2. Hersh Shefrin, Christina.M.Nicols (2014) in her study "credit card behavior, financial styles, and heuristics" January, 2011 extracted from research gate.

3. Kubra Onder (2018)in his study, "The outcome of credit card utilization on customer's behavior" issued in International journal of Eurasia Social Sciences 9(32):1099-1120 June, 2018.

4. Leo Vashkor Dewri (2016) in his research, "Behavioral Analysis of credit card users in anemerging country: a case of Bangladesh" March,2016.

5. Wesley Mendes-Da-Silva (2012) in his study "credit card risk behavior on college campuses: evidence from Brazil" issued in Brazilian Administration Review 9(3), July, 2012.

\section{AUTHORS PROFILE}

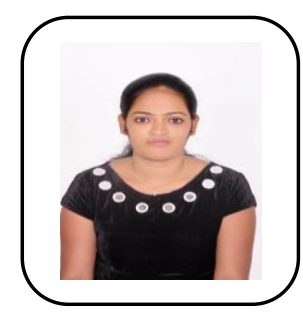

Ms. Jannifer Rani.N has completed her post graduate in commerce and has worked in Bharath University for one year as Assistant Professor. She has presented research papers in international conferences published in UGC care journals.

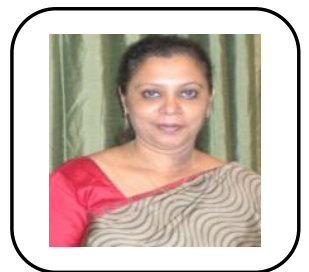

Dr. Anli Suresh joined the department as a faculty in the year 2004. Her area of specialization is Finance. Her doctoral research was on "A STUDY ON PARADIGM SHIFT IN FINANCIAL INNOVATION AND CAPITAL FORMATION IN INDIAN FINANCIAL SYSTEM WITH REFERENCE TO POST LIBERALIZATION ERA". She has also cleared NET, the National Eligibility Test for lectureship conducted by University Grants Commission, India. She has presented many research papers in national and international conferences organized by various universities across the county and her papers awarded as best paper in many conferences. Her research and teaching interests include Financial Management, Quantitative Techniques with SPSS, Brand Management, Income Tax, Banking, Organizational Behavior, Strategic Marketing, Training and Development, Services Marketing, Accounting for Decision Making. She has published more than 100 of her research papers in various reputed referred national, international journals and books and organized many international conferences. She is also in the editorial board of international journals to her credit. In the year 2010-2011, Ms. Anli was chosen as the distinguished fellow of Global Strategic Management Inc, Michigan, USA. 